\title{
Extracellular enzymatic profiles and taxonomic identification of endophytic fungi isolated from four plant species
}

R.N. Alberto ${ }^{1}$, A.T. Costa ${ }^{1}$, J.C. Polonio ${ }^{1}$, M.S. Santos ${ }^{1}$, S.A. Rhoden ${ }^{2}$, J.L. Azevedo ${ }^{3}$ and J.A. Pamphile ${ }^{1}$

${ }^{1}$ Departamento de Biotecnologia, Genética e Biologia Celular, Universidade Estadual de Maringá, Maringá, PR, Brasil

${ }^{2}$ Instituto Federal Catarinense, Campus de São Francisco do Sul, Brasil

${ }^{3}$ Departamento de Genética, Escola Superior de Agricultura "Luiz de Queiroz", Universidade de São Paulo, Piracicaba, SP, Brasil

Corresponding author: J.A. Pamphile

E-mail: prof.pamphile@gmail.com

Genet. Mol. Res. 15 (4): gmr15049016

Received July 21, 2016

Accepted September 12, 2016

Published November 3, 2016

DOI http://dx.doi.org/10.4238/gmr15049016

Copyright $(\underset{2016}{ }$ The Authors. This is an open-access article distributed under the terms of the Creative Commons Attribution ShareAlike (CC BY-SA) 4.0 License.

\begin{abstract}
Plants of medicinal and economic importance have been studied to investigate the presence of enzyme-producing endophytic fungi. The characterization of isolates with distinct enzyme production potential may identify suitable alternatives for specialized industry. At Universidade Estadual de Maringá Laboratory of Microbial Biotechnology, approximately 500 isolates of endophytic fungi have been studied over the last decade from various host plants, including medicinally and economically important species, such as Luehea divaricata (Martius et Zuccarini), Trichilia elegans A. Juss, Sapindus saponaria L., Piper hispidum Swartz, and Saccharum spp. However, only a fraction of these endophytes have been identified and evaluated
\end{abstract}


for their biotechnological application, having been initially grouped by morphological characteristics, with at least one representative of each morphogroup tested. In the current study, several fungal strains from four plants (L. divaricata, T. elegans, S. saponaria, and Saccharum spp) were identified by ribosomal DNA typing and evaluated semi-quantitatively for their enzymatic properties, including amylase, cellulase, pectinase, and protease activity. Phylogenetic analysis revealed the presence of four genera of endophytic fungi (Diaporthe, Saccharicola, Bipolaris, and Phoma) in the plants examined. According to enzymatic tests, $62 \%$ of the isolates exhibited amylase, approximately $93 \%$ cellulase, $50 \%$ pectinase, and $64 \%$ protease activity. Our results verified that the composition and abundance of endophytic fungi differed between the plants tested, and that these endophytes are a potential enzyme production resource of commercial and biotechnological value.

Key words: Endophytes; Fungi; Phylogenetic analysis; Enzymes

\section{INTRODUCTION}

Endophytic fungi exhibit complex interactions with their hosts. This fact has recently triggered several studies exploring their utilization as sources of novel bioactive natural products. Although the production of metabolites depends on several factors, fungi employ molecular pathways resulting in specific compounds. The products of these metabolic processes include important drugs such as penicillin and statins, and toxic substances such as aflatoxins (Keller et al., 2005).

Endophytic fungi synthesize a wide range of enzymes and natural products that demonstrate a variety of biological activities (Kusari et al., 2014). The bioactive secondary metabolites produced by such organisms include compounds that mimic metabolites synthesized by the host plant (Kusari et al., 2014). The production of novel compounds by endophytic fungi is of great pharmaceutical, industrial, and agricultural importance, since these metabolites may be unique in their structure and effective against several diseases (Mishra et al., 2014). For instance, Suryanarayanan et al. (2009) described several natural compounds with antifungal and antibacterial activity isolated from fungi.

Enzymes are potential biocatalysts for a large number of reactions. Microorganisms represent a viable alternative source of enzymes, as they may be cultured in large quantities within short time frames by fermentation, are biochemically diverse, and are amenable to genetic manipulation (Anbu et al., 2013).

Fungal endophytes produce several extracellular enzymes, such as pectinases, cellulases, lipases, amylases, laccases, and proteinases. Moreover, fungal enzymes play a key role in biodegradation and hydrolysis, mechanisms of significant importance in protection against invading pathogens, besides being crucial in obtaining nutrition from the host plant (Sunitha et al., 2013). Indeed, their principal functions comprise hydrolysis of food substances and defense against pathogens (Desire et al., 2014). Fungal enzymes are used in the beverage, food, confectionary, textile, and leather industries to simplify the processing of raw materials. In addition, such enzymes are often more stable than those derived from other sources (Raju et al., 2015).

The medicinal properties of certain plants may be related to the metabolites produced

Genetics and Molecular Research 15 (4): gmr15049016 
by associated endophytic microorganisms. Endophytes isolated from such plants generate strongly fungicidal, bactericidal, and cytotoxic molecules, and produce enzymes used in various applications, including the degradation and biotransformation of organic compounds (Sudha et al., 2016).

Due to the great diversity of Brazilian flora, the isolation and the characterization of these microorganisms, especially those associated with plants of medicinal and economic significance may be highly beneficial. The plants Luehea divaricata, Trichilia elegans, Sapindus saponaria, and Saccharum spp are used in traditional culture for the treatment of several diseases, and have also attracted commercial interest. Bernardi-Wenzel et al. (2010), Rhoden et al. (2012), García et al. (2012), and Leme et al. (2013) demonstrated the presence of endophytes in each of these plants, respectively. Although some endophytic fungi associated with these species have already been studied by our group, this represents only a fraction of the total number of fungal and bacterial isolates obtained from these plants belonging to our microbial laboratory collection, since endophytes were initially grouped by morphological characteristics, with representatives of each morphogroup being examined. Therefore, in the present study, with the aim of continuing the study of these previously isolated microorganisms, we sought to screen further endophytic fungi present in these plants to assess their biotechnological potential as enzyme producers. Furthermore, taxonomic identification of some of the endophytes in our fungal collection was carried out.

\section{MATERIAL AND METHODS}

\section{Biological material}

The endophytic fungi used in the current research were as follows: 8 isolates from $L$. divaricata Martius et Zuccarini (Bernardi-Wenzel et al., 2010); 10 isolates from T. elegans A. Juss (Rhoden et al., 2012); 11 isolates from S. saponaria L. (García et al., 2012); and 13 isolates from Saccharum spp (Leme et al., 2013), belonging to the collection of the Laboratory of Microbial Biotechnology of Universidade Estadual de Maringá, Maringá, PR, Brazil. The fungi were selected from the same morphogroup, considering colony morphology and coloration, mycelial form, and pigment production of each isolate.

\section{Molecular identification of endophytic fungi}

Genomic DNA was extracted following Raeder and Broda (1985) with modifications according to Pamphile and Azevedo (2002), except that beforehand, endophytes were grown for 7 days on plates containing potato dextrose broth medium at $28^{\circ} \mathrm{C}$ without agitation. The concentration and purity of genomic DNA were determined with a GENESYS 10S UV-Vis spectrophotometer (Thermo Scientific, Waltham, MA, USA) by measuring the 260/280 nm optical density ratio. DNA integrity was analyzed by electrophoresis on $1 \%$ agarose gels, using a High DNA Mass Ladder (Invitrogen, Carlsbad, CA, USA) as a molecular weight standard. The final DNA concentration was adjusted to $10 \mathrm{ng} / \mathrm{mL}$.

Polymerase chain reaction (PCR) amplification of the internal transcribed spacer (ITS)1-5.8S-ITS2 ribosomal DNA (rDNA) region was performed using primers ITS1 (5'-TCCGTAGGTGAACCTGCGG-3') and ITS4 (5'-TCCCCGCTTATTGATATGC-3'; White et al., 1990), with an initial denaturation at $92^{\circ} \mathrm{C}$ for $4 \mathrm{~min}$, followed by 35 cycles of denaturation at $92^{\circ} \mathrm{C}$ for $40 \mathrm{~s}$, annealing at $52^{\circ} \mathrm{C}$ for $1 \mathrm{~min} 30 \mathrm{~s}$, and extension at $72^{\circ} \mathrm{C}$ for 2

Genetics and Molecular Research 15 (4): gmr15049016 
min, before a final extension at $72^{\circ} \mathrm{C}$ for $5 \mathrm{~min}$.

PCR products were purified with a GFX PCR DNA and Gel Band Purification Kit (Amersham Biosciences, Amersham, UK) following the manufacturer protocol, and prepared for sequencing reactions using primer ITS4. Sequencing reactions were performed in a thermocycler as follows: initial denaturation at $95^{\circ} \mathrm{C}$ for $2 \mathrm{~min}$, followed by 35 cycles of denaturation at $95^{\circ} \mathrm{C}$ for $1 \mathrm{~min}$, annealing at $55^{\circ} \mathrm{C}$ for $1 \mathrm{~min}$, and extension at $60^{\circ} \mathrm{C}$ for $1 \mathrm{~min}$, prior to a final extension at $60^{\circ} \mathrm{C}$ for $5 \mathrm{~min}$. Sequencing was performed in a MegaBACE 1000 sequencer (Amersham Biosciences), with injection and electrophoresis conditions of $1 \mathrm{kV}$ for $90 \mathrm{~s}$ and $7 \mathrm{kV}$ for $240 \mathrm{~min}$, respectively.

The nucleotide sequences were analyzed, edited, and compared to homologous sequences deposited in GenBank (http://www.ncbi.nlm.nih.gov). For determination of genera and species, the BLASTN algorithm was used, based on the highest identity value obtained.

Phylogenetic analysis involved the construction of a dendrogram using the sequences obtained as above, together with those available in GenBank. Sequences were aligned using ClustalX and the dendrogram generated in MEGA5 (Tamura et al., 2011) by the neighborjoining method with nucleotide p-distances, pairwise gap deletion, and 10,000 bootstrap (BP) replicates. All 16S rDNA gene sequences in the current study were deposited in GenBank under accession Nos. KX530728 through KX530754.

\section{Assessment of biotechnologically relevant enzyme activity of endophytic isolates by cup-plate assay}

Endophytic isolates were cultured on potato dextrose agar medium for 7 days before analysis of their amylase, cellulase, pectinase, and protease capacities. Three 5-mm mycelial discs per isolate were cultured in liquid medium (Manachini solution; $2 \mathrm{~g} / \mathrm{L} \mathrm{KH}_{2} \mathrm{PO}_{4}, 1 \mathrm{~g} / \mathrm{L}$ $\left(\mathrm{NH}_{4}\right)_{2} \mathrm{SO}_{4}, 0.1 \mathrm{~g} / \mathrm{L} \mathrm{MgSO} \cdot 7 \mathrm{H}_{2} \mathrm{O}, 0.9 \mathrm{~g} / \mathrm{L} \mathrm{Na}_{2} \mathrm{HPO}_{4} \cdot 2 \mathrm{H}_{2} \mathrm{O}, 1 \mathrm{~g} / \mathrm{L}$ yeast extract, and $1 \mathrm{~L}$ distilled water) supplemented with $0.5 \%$ substrate and a $\mathrm{pH}$ value adjusted to the corresponding enzyme, as follows: amylase (corn starch, $\mathrm{pH}$ 6.0); cellulase [carboxymethyl cellulose (CMC; Fluka, Gillingham, UK), pH 5.0]; pectinase [citrus pectin (Vetec, Duque de Caxias, Brazil), pH 2.5], and protease (gelatin, $\mathrm{pH}$ 6.9). Cultures were incubated at $28^{\circ} \mathrm{C}$ with shaking at $140 \mathrm{rpm}$ for 96 or $120 \mathrm{~h}$. Mycelia were then separated from the liquid medium with sterilized gauze. A disc 6 $\mathrm{mm}$ in diameter was removed from the center of the Petri dish of solid enzyme detection medium (cup plates) and the resulting hole filled with $50 \mu \mathrm{L}$ filtered liquid medium. Starch agar $(18 \mathrm{~g} / \mathrm{L}$ agar, $10 \mathrm{~g} / \mathrm{L}$ starch, and $0.1 \mathrm{M}$ citrate-phosphate buffer, $\mathrm{pH}$ 5.0) was used for amylase; CMC agar (18 g/L agar, $10 \mathrm{~g} / \mathrm{L} \mathrm{CMC}$, and $0.1 \mathrm{M} \mathrm{Na}^{+}$acetate buffer, $\mathrm{pH}$ 5.0) for cellulase; pectin agar (18 g/L agar, $10 \mathrm{~g} / \mathrm{L}$ pectin, and $0.1 \mathrm{M} \mathrm{Na}^{+}$acetate buffer, $\mathrm{pH}$ 5.0) for pectinase; and gelatin milk agar (18 g/L agar, $10 \%$ gelatin solution, $10 \%$ skim milk solution, and $0.1 \mathrm{M}$ citrate-phosphate buffer, $\mathrm{pH}$ 5.0) for protease. The following commercially available enzymes (Sigma-Aldrich, St. Louis, MO, USA) were used as positive controls: porcine pancreatic $\alpha$-amylase; Aspergillus sp cellulase; Aspergillus niger pectinase; and Aspergillus oryzae protease. The negative control consisted of liquid medium incubated without fungal inoculation.

The experiment was performed in triplicate, and plates were incubated at $28^{\circ} \mathrm{C}$ for between 24 and $168 \mathrm{~h}$. Enzymatic activity was evaluated by the presence of a clear halo with an opalescent background, the size of which was measured in millimeters. With the exception of protease, they were visualized with indicators specific for each enzyme, as follows: iodine tincture (amylase); Congo red dye (cellulase); and $5 \mathrm{~N} \mathrm{HCl}$ (pectinase).

Genetics and Molecular Research 15 (4): gmr15049016 


\section{Statistical analyses}

All experiments were performed using a completely randomized design, and results were tested by analysis of variance and the $F$-test. Means were compared by the Scott-Knott test $(\mathrm{P}<0.05)$ in the statistical program Sisvar 5.4 (Ferreira, 2011).

\section{RESULTS}

\section{Molecular taxonomy based on rDNA and phylogenetic analysis of endophytic fungi}

In the current study, taxonomic identification was achieved for 27 of the 42 endophytic fungi tested for enzyme function (Table 1).

Table 1. Identification of endophytic fungi isolated from Luehea divaricata, Trichilia elegans, Sapindus saponaria, and Saccharum spp based on sequencing of the ribosomal DNA internal transcribed spacer (ITS)15.8S-ITS2 region.

\begin{tabular}{|c|c|c|c|c|c|c|}
\hline \multirow[t]{2}{*}{ Host plant } & \multirow[t]{2}{*}{ Strain } & \multicolumn{4}{|c|}{ BLAST (GenBank) } & \multirow[t]{2}{*}{ Taxonomic identification ${ }^{3}$} \\
\hline & & General alignment $^{1}$ & Identity & Type material alignment ${ }^{2}$ & Identity & \\
\hline \multirow{5}{*}{ Luehea divaricata } & G17 & AY745986.1 & $98 \%$ & KJ197286.1 & $97 \%$ & Diaporthe $\mathrm{sp}$ \\
\hline & G28 & KM979780.1 & $99 \%$ & KJ197286.1 & $99 \%$ & Diaporthe $\mathrm{sp}$ \\
\hline & G30 & KP182396.1 & $98 \%$ & NR_120155.1 & $96 \%$ & Diaporthe $\mathrm{sp}$ \\
\hline & G10 & KM454881.1 & $100 \%$ & KF777180.1 & $99 \%$ & Phoma sp \\
\hline & G13 & KR093844.1 & $99 \%$ & NR_111850.1 & $99 \%$ & Diaporthe $\mathrm{sp}$ \\
\hline \multirow[t]{6}{*}{ Trichilia elegans } & $2-5$ & GQ461581.1 & $99 \%$ & KC343136.1 & $96 \%$ & Diaporthe $\mathrm{sp}$ \\
\hline & $3-17.1 .11$ & GQ461582.1 & $99 \%$ & NR_111850.1 & $97 \%$ & Diaporthe $\mathrm{sp}$ \\
\hline & $3-2.2 .1$ & KR093844.1 & $99 \%$ & KP004461.1 & $99 \%$ & Diaporthe $\mathrm{sp}$ \\
\hline & $2-68$ & KM999227.1 & $99 \%$ & KP004461.1 & $96 \%$ & Diaporthe $\mathrm{sp}$ \\
\hline & $2-1$ & KM979832.1 & $99 \%$ & KM453210.1 & $97 \%$ & Diaporthe $\mathrm{sp}$ \\
\hline & $2-58$ & KC145910.1 & $99 \%$ & KJ197287.1 & $96 \%$ & Diaporthe $\mathrm{sp}$ \\
\hline \multirow[t]{5}{*}{ Sapindus saponaria } & Ss15 & KP881432.1 & $97 \%$ & FJ427025.1 & $99 \%$ & Phoma sp \\
\hline & Ss27 & JQ753978.1 & $85 \%$ & KJ415528.1 & $85 \%$ & Bipolaris sp \\
\hline & Ss69 & KC981121.1 & $92 \%$ & KJ590728.1 & $91 \%$ & Diaporthe $\mathrm{sp}$ \\
\hline & Ss01B & KC343053.1 & $98 \%$ & NR_111862.1 & $97 \%$ & Diaporthe $\mathrm{sp}$ \\
\hline & Ss49 & KM999227.1 & $99 \%$ & KP004461.1 & $97 \%$ & Diaporthe $\mathrm{sp}$ \\
\hline \multirow[t]{11}{*}{ Saccharum spp } & C55 & KP881432.1 & $97 \%$ & KF251258.1 & $87 \%$ & Saccharicola $\mathrm{sp}$ \\
\hline & C58 & GQ370379.1 & $98 \%$ & KF251258.1 & $94 \%$ & Saccharicola $\mathrm{sp}$ \\
\hline & $\mathrm{C} 40$ & GQ370379.1 & $99 \%$ & KF251258.1 & $96 \%$ & Saccharicola $\mathrm{sp}$ \\
\hline & C61 & GQ370379.1 & $97 \%$ & KF251258.1 & $96 \%$ & Saccharicola $\mathrm{sp}$ \\
\hline & $\mathrm{C} 20$ & GQ461582.1 & $99 \%$ & KC343136.1 & $96 \%$ & Diaporthe $\mathrm{sp}$ \\
\hline & $\mathrm{C} 34$ & GQ370379.1 & $99 \%$ & KF251258.1 & $95 \%$ & Saccharicola $\mathrm{sp}$ \\
\hline & $\mathrm{C} 35$ & GQ370379.1 & $99 \%$ & KF251258.1 & $95 \%$ & Saccharicola $\mathrm{sp}$ \\
\hline & $\mathrm{C} 36$ & GQ370379.1 & $99 \%$ & KF251258.1 & $95 \%$ & Saccharicola $\mathrm{sp}$ \\
\hline & $\mathrm{C} 42$ & GQ370379.1 & $100 \%$ & KF251258.1 & $96 \%$ & Saccharicola $\mathrm{sp}$ \\
\hline & $\mathrm{C} 24$ & GQ370379.1 & $99 \%$ & KF251258.1 & $95 \%$ & Saccharicola $\mathrm{sp}$ \\
\hline & C56 & GQ370379.1 & $99 \%$ & KF251258.1 & $95 \%$ & Saccharicola $\mathrm{sp}$ \\
\hline
\end{tabular}

${ }^{1}$ Accession numbers with highest identity values when compared to endophytic fungal isolate sequences using BLAST searches and the GenBank database; ${ }^{2}$ BLAST alignment limited to type materials available in GenBank; ${ }^{3}$ taxonomic identification based on the phylogenetic analysis.

Phylogenetic analysis revealed four main clades (A, B, C, and D; Figure 1), including sub-clades (A1, B2 and D1). Sub-clade A1, with 100\% BP support, grouped isolates of the Diaporthe genus (including type strains). At least one fungal endophyte associated with each host plant featured in this clade: 2-5, 3-17.1.11, 2-58, 2-1, 2-68, and 3-2.2.1 isolated from $T$. elegans; Ss69, Ss01B, and Ss49 isolated from S. saponaria; G30, G13, G28, and G17 isolated from L. divaricata; and C20 associated with Saccharum spp (Figure 1).

Genetics and Molecular Research 15 (4): gmr15049016 
Sub-clade B2 clustered isolates C55, C58, C40, C61, C42, C36, C24, C35, C34, and C56 belonging to the genus Saccharicola with 54\% BP support. Clade C, supported by $100 \%$ of the BP replicates, revealed isolate Ss27 from S. saponaria to be Bipolaris sp. Finally, subclade D1, with $85 \%$ BP support, grouped G10 from L. divaricata and Ss15 of S. saponaria with isolates of the genus Phoma (Figure 1).

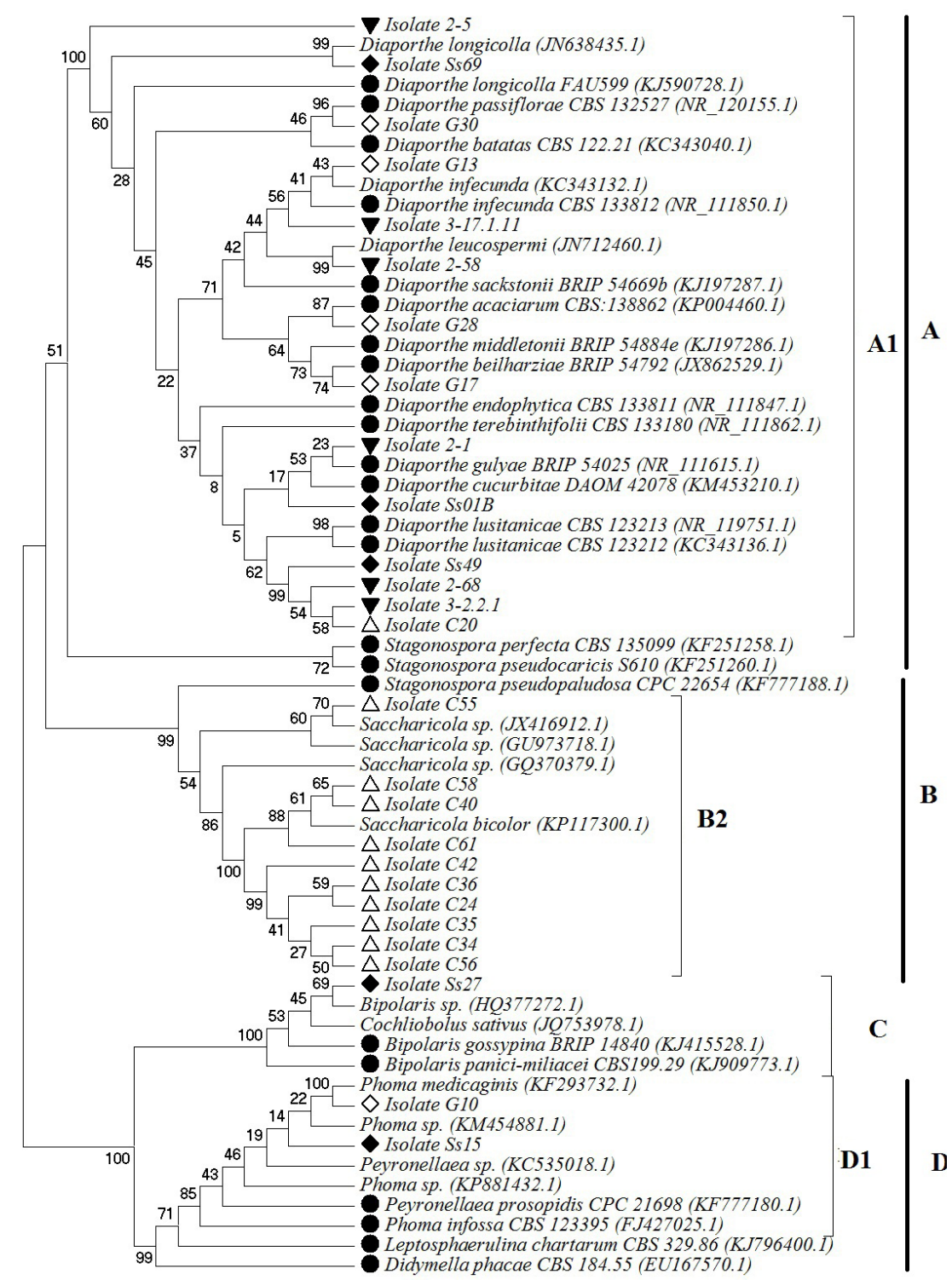

Figure 1. Phylogenetic relationships between sequences of endophytic fungi isolated from Luehea divaricata, Trichilia elegans, Sapindus saponaria, and Saccharum spp and those of other fungi deposited in GenBank. Filled triange $=$ isolates from Trichilia elegans; open triangle $=$ isolates from Saccharum spp; filled diamond $=$ isolates from Sapindus saponaria; open diamond = isolates from Luehea divaricate; filled circle = type strains.

Genetics and Molecular Research 15 (4): gmr15049016 


\section{Enzymatic activity}

Evaluation of the enzymatic properties of endophytic fungal isolates obtained from the four plant species showed that $62 \%$ exhibited amylase, approximately $93 \%$ cellulase, $50 \%$ pectinase, and $64 \%$ protease activity.

According to our statistical analyses (Table 2), isolates G16 and G30 of L. divaricata, 2-58 of T. elegans, Ss73 of S. saponaria, and C58 and C16 of Saccharum spp showed significantly larger halos of enzymatic action (HEA) in relation to amylase activity, compared to other isolates of the same plants. Isolates Ss73 of S. saponaria and C58 and C16 of Saccharum spp produced HEAs of 11.8, 13.4, and $12.0 \mathrm{~mm}$, respectively, larger than those resulting from the positive control enzyme.

Table 2. evaluation of the enzyme activitiesof endophytic fungi isolated from Luehea divaricata, Trichilia elegans, Sapindus saponaria, and Saccharum spp.

\begin{tabular}{|c|c|c|c|c|c|}
\hline \multicolumn{2}{|l|}{ Isolate } & \multicolumn{4}{|c|}{ Halo of enzymatic action $(\mathrm{mm})^{1,2}$} \\
\hline & & Amylase & Cellulase & Pectinase & Protease \\
\hline \multirow{8}{*}{ Luehea divaricata } & G16 & $10.2^{\mathrm{d}}$ & $12.2^{\mathrm{g}}$ & - & $12.2^{\mathrm{i}}$ \\
\hline & G30 & $10.2^{\mathrm{d}}$ & $16.2^{\mathrm{c}}$ & $8.0^{\mathrm{b}}$ & $18.6^{\mathrm{c}}$ \\
\hline & G28 & $9.4^{\mathrm{f}}$ & $15.0^{\mathrm{d}}$ & $8.0^{\mathrm{b}}$ & $13.5^{\mathrm{h}}$ \\
\hline & G17 & $9.2^{\mathrm{g}}$ & $16.0^{\mathrm{c}}$ & - & $20.0^{\mathrm{a}}$ \\
\hline & G10 & $9.1^{\mathrm{g}}$ & $14.9^{\mathrm{d}}$ & - & - \\
\hline & G13 & $8.6^{\mathrm{h}}$ & $13.6^{\mathrm{e}}$ & - & $15.0^{\mathrm{g}}$ \\
\hline & G21 & $8.3^{\mathrm{h}}$ & $10.4^{\mathrm{i}}$ & $8.0^{\mathrm{b}}$ & $15.8^{\mathrm{e}}$ \\
\hline & G14 & - & $15.3^{\mathrm{d}}$ & - & $8.0^{1}$ \\
\hline \multirow[t]{10}{*}{ Trichilia elegans } & $2-58$ & $9.8^{\mathrm{c}}$ & $13.1^{f}$ & - & $15.0^{\mathrm{g}}$ \\
\hline & $2-1$ & $9.5^{\mathrm{f}}$ & $15.7^{\mathrm{c}}$ & - & $10.0^{\mathrm{k}}$ \\
\hline & $2-23$ & $9.0^{\mathrm{g}}$ & $14.9^{\mathrm{d}}$ & $8.0^{\mathrm{b}}$ & $10.0^{\mathrm{k}}$ \\
\hline & $3-2.2 .1$ & $8.0^{\mathrm{i}}$ & $10.3^{\mathrm{i}}$ & - & $15.3^{\mathrm{f}}$ \\
\hline & $3-1.2 .1$ & - & $9.9^{\mathrm{j}}$ & - & $19.2^{\mathrm{b}}$ \\
\hline & $2-68$ & - & $11.8^{\mathrm{h}}$ & $8.0^{\mathrm{b}}$ & $20.0^{\mathrm{a}}$ \\
\hline & $3-17.1 .11$ & - & $10.8^{\mathrm{i}}$ & $8.0^{\mathrm{b}}$ & $16.3^{\mathrm{d}}$ \\
\hline & $2-5$ & - & $10.6^{\mathrm{i}}$ & $8.0^{\mathrm{b}}$ & - \\
\hline & $2-42$ & - & - & $8.0^{\mathrm{b}}$ & - \\
\hline & $2-43$ & - & $12.4^{\mathrm{g}}$ & $8.0^{\mathrm{b}}$ & $13.4^{\mathrm{h}}$ \\
\hline \multirow[t]{11}{*}{ Sapindus saponaria } & Ss73 & $11.8^{\mathrm{b}}$ & $14.0^{\mathrm{e}}$ & $8.0^{\mathrm{b}}$ & $12.0^{\mathrm{j}}$ \\
\hline & Ss69 & $10.0^{\mathrm{e}}$ & $16.8^{\mathrm{b}}$ & - & $15.0^{\mathrm{g}}$ \\
\hline & Ss27 & $9.8^{\mathrm{e}}$ & - & $8.0^{\mathrm{b}}$ & - \\
\hline & Ss16 & $9.0^{\mathrm{g}}$ & $9.6^{\mathrm{j}}$ & - & $16.0^{\mathrm{e}}$ \\
\hline & Ss52 & $9.0^{\mathrm{g}}$ & $10.2^{\mathrm{i}}$ & - & $20.0^{\mathrm{a}}$ \\
\hline & Ss15 & $8.0^{\mathrm{i}}$ & $11.3^{\mathrm{h}}$ & - & - \\
\hline & $\begin{array}{l}\text { Ss01B } \\
\end{array}$ & - & $12.1^{\mathrm{h}}$ & $8.0^{\mathrm{b}}$ & $20.0^{\mathrm{a}}$ \\
\hline & Ss31 & - & $12.4^{\mathrm{g}}$ & - & $20.0^{\mathrm{a}}$ \\
\hline & Ss34 & - & $11.8^{\mathrm{h}}$ & $8.0^{\mathrm{b}}$ & $13.4^{\mathrm{h}}$ \\
\hline & Ss49 & - & $10.0^{\mathrm{j}}$ & - & - \\
\hline & Ss50 & - & $10.7^{\mathrm{i}}$ & - & $12.3^{\mathrm{i}}$ \\
\hline \multirow[t]{13}{*}{ Saccharum spp } & $\mathrm{C} 58$ & $13.4^{\mathrm{a}}$ & $11.3^{\mathrm{h}}$ & $8.0^{\mathrm{b}}$ & $12.0^{\mathrm{j}}$ \\
\hline & C16 & $12.0^{\mathrm{b}}$ & $13.7^{\mathrm{e}}$ & - & - \\
\hline & $\mathrm{C} 24$ & $10.6^{\mathrm{d}}$ & $9.3^{j}$ & $8.0^{\mathrm{b}}$ & - \\
\hline & C34 & $10.4^{\mathrm{d}}$ & $11.2^{\mathrm{h}}$ & - & $7.4^{\mathrm{m}}$ \\
\hline & $\mathrm{C} 40$ & $10.4^{\mathrm{d}}$ & $12.0^{\mathrm{h}}$ & $8.0^{\mathrm{b}}$ & $8.0^{1}$ \\
\hline & C61 & $10.2^{\mathrm{d}}$ & $10.2^{\mathrm{i}}$ & $8.0^{\mathrm{b}}$ & - \\
\hline & $\mathrm{C} 42$ & $9.8^{\mathrm{e}}$ & $11.7^{\mathrm{h}}$ & - & - \\
\hline & C60 & $9.8^{\mathrm{e}}$ & $9.7^{\mathrm{j}}$ & $7.3^{\mathrm{c}}$ & - \\
\hline & $\mathrm{C} 35$ & $8.9^{\mathrm{g}}$ & $11.4^{\mathrm{h}}$ & $6.6^{\mathrm{d}}$ & - \\
\hline & $\mathrm{C} 20$ & - & $11.5^{\mathrm{h}}$ & - & - \\
\hline & C36 & - & $10.7^{\mathrm{i}}$ & - & - \\
\hline & C55 & - & $11.9^{\mathrm{h}}$ & - & $7.7^{\mathrm{m}}$ \\
\hline & C56 & - & - & $8.0^{\mathrm{b}}$ & - \\
\hline Positive controls & & $11.0^{\mathrm{c}}$ & $27.0^{\mathrm{a}}$ & $13.0^{\mathrm{a}}$ & $20.0^{\mathrm{a}}$ \\
\hline
\end{tabular}

${ }^{1}$ Means followed by the same letter in the same column do not differ according to the Scott-Knott test $(<0.05)$. ${ }^{2}$ For values less than or equal to 6.0 , no halo was considered to have formed.

Genetics and Molecular Research 15 (4): gmr15049016 
Regarding cellulase activity, isolates G30 and G17 from L. divaricata, 2-1 from $T$. elegans, Ss69 from S. saponaria, and C16 from Saccharum spp generated significantly bigger HEAs (16.2, 16.0, 15.7, 16.8, and $13.7 \mathrm{~mm}$, respectively; Table 2) than other isolates of the same plants. However, none produced an HEA larger than that of the positive control.

Of the enzymes tested, the activity of pectinase was the lowest, with isolates C60 and C35 from Saccharum spp. demonstrating particularly reduced activity (HEAs of 7.3 and $6.6 \mathrm{~mm}$, respectively; Table 2). None of the isolates from any of the four plants produced pectinase with an HEA higher than that of the positive control.

In tests for protease activity, isolates G17 of L. divaricata, 2-68 of T. elegans, and Ss52, Ss01B, and Ss31 of S. saponaria demonstrated HEAs significantly larger than those of the other fungi examined (all $20.0 \mathrm{~mm}$; Table 2), and of a similar size to that observed with the positive control.

\section{DISCUSSION}

Several studies have reported the isolation of large numbers of endophytes from plants of medicinal and great economic importance. As in the current analysis, fungi of the genus Diaporthe were identified in investigations by Bernardi-Wenzel et al. (2010), Rhoden et al. (2012), García et al. (2012), and Leme et al. (2013). Rhoden et al. (2012) found members of the genus Diaporthe (Phomopsis) to be the most frequently observed endophytic species.

Diaporthe species (and their Phomopsis asexual states) have broad host ranges and are widely distributed, occurring as plant pathogens, endophytes, or saprobes, but also as pathogens of humans and other mammals. Diaporthe has been described as one of the most common genera of endophytic fungi in several plant hosts. Organisms in this genus have also been acknowledged as producers of interesting enzymes and secondary metabolites with antibiotic and anticancer activity (Gomes et al., 2013).

Leme et al. (2013) studied endophytic fungal communities isolated from sugarcane (Saccharum spp) leaves, identifying five genera, including Saccharicola (Massarinaceae). This genus was defined by Eriksson and Hawksworth (2003) to accommodate Leptosphaeria bicolor and Leptosphaeria taiwanensis, the Stagonospora-like asexual morphs of which were described by these authors.

Fungi of the genus Saccharicola were also identified in a study by Almeida et al. (2015) as part of an endophytic fungal community associated with the aquatic macrophytes Eichhornia azurea (Kunth) and Eichhornia crassipes (Mart.) of the Pontederiaceae family.

Endophytes of the genus Bipolaris were previously isolated from S. saponaria as Cochliobolus, their sexual morph (García et al., 2012). This genus was also recorded in studies by Bernardi-Wenzel et al. (2010), isolated from L. divaricata, and Orlandelli et al. (2012), from Piper hispidum. In the latter study, the authors evaluated the colonization of $P$. hispidum by foliar endophytic fungi and the diversity of such species in this medicinal plant, identifying 21 isolates belonging to 11 genera, with Bipolaris being the most frequently observed genus among the identified endophytes.

Furthermore, Bipolaris fungi have been isolated from medicinal and aquatic plants (Sakayaroj et al., 2010; Almeida et al., 2015). Members of this genus are the most widely distributed phytopathogens, and include species commonly associated with leaf spot, leaf blight, melting out, root rot, foot rot, and other disease symptoms that principally affect highvalue crops of the Poaceae family (Manamgoda et al., 2014).

Genetics and Molecular Research 15 (4): gmr15049016 
Various strains of the genus Phoma have been isolated from several medicinal plants, such as L. divaricata (Bernardi-Wenzel et al., 2010), S. saponaria (García et al., 2012), Arisaema erubescens (Wang et al., 2012), P. hispidum (Orlandelli et al., 2012), Tinospora cordifolia, Calotropis procera (Kedar et al., 2014), and Curcuma longa (Gupta et al., 2016). In the current study, Phoma isolates were only identified in samples of L. divaricata and S. saponaria. Phoma species are geographically widespread and comprise a large fungal group occupying diverse ecological niches. Although harmless saprobic examples abound, some Phoma species are wellknown phytopathogens of economically important plants (Rai et al., 2014).

The use of endophytic fungi in various industrial processes has triggered an increasing number of studies concerning these microorganisms, and consequently, the discovery of novel compounds with enormous potential in a variety of applications (Meng et al., 2011; Duza and Mastan, 2013).

In addition to the great diversity of primary and secondary metabolites produced by endophytic fungi, a range of enzymes are also generated by these microorganisms (Bezerra et al., 2015). D'Souza and Hiremath (2015) performed qualitative amylase, cellulase, and pectinase assays of endophytic fungi isolated from 21 plants used in traditional medicine from forests of the Western Ghats, Goa, India. The authors verified that production of cellulase was common $(45.07 \%)$, followed by that of amylase (36.62\%), and pectinase $(18.31 \%)$. In a similar study, Patil et al. (2015) qualitatively and quantitatively screened endophytic fungi extracted from seven medicinal plants for the production of extracellular enzymes, including amylase, protease, cellulase, and lipase. Their qualitative assay showed that of these enzymes, protease activity was most frequently observed, followed by cellulase, amylase, and lipase activity.

With a wide variety of industrial applications, such as in the food, fermentation, textile, paper, detergent, pharmaceutical, and sugar industries, amylases are important enzymes that may be employed in polysaccharide hydrolysis for the processing of starch. Amylases are derived from several sources, including plants, animals, and microorganisms. Enzymes from microbial sources are generally more suited to industrial demands, being cheaper to produce and more predictable, controllable, and reliable. A. niger is used for the commercial synthesis of amylase because of its high production capacity (de Souza and de Oliveira Magalhães, 2010; Jain et al., 2012).

In terms of production, cellulases are the third most industrially significant enzymes worldwide, because of their utility in applications and products such as cotton processing, paper recycling, juice extraction, enzymatic detergents, and animal food additives. Filamentous fungi are widely used in industry for the generation of cellulases, especially those of the genera Aspergillus, Trichoderma, Humicola, Penicillium, Fusarium, and Phanerochaete (Onofre et al., 2013).

Endophytic and pathogenic fungi induce the production of pectinases in the presence of pectic substances. Microbial pectinases are important enzymes in phytopathologic processes, plant-microbe symbiosis, and decomposition of dead plant material. Degradation of host tissue by phytopathogens generally begins with the production of pectinolytic enzymes, the major enzymes involved in plant pathogenesis. Endophytes that degrade pectic substances are likely to be latent pathogens (Choi et al., 2005; Sunitha et al., 2013).

The cellulase and pectinase activity of endophytic fungi isolated from oil-bearing seeds and medicinal plants has been described by Venkatesagowda et al. (2012) and Sunitha et al. (2013). Extracellular hydrolytic enzymes produced by fungal endophytes, particularly cellulase and pectinase, provide host-derived nutrients and resistance against pathogenic microbial infection.

Genetics and Molecular Research 15 (4): gmr15049016 
Proteases represent two-thirds of global industrial enzyme requirements. They have a host of applications, notably in industrial bioremediation processes and the pharmaceutical and food industries, among others (Vardhini and Irfath, 2013; Orlandelli et al., 2015). Proteases are used in clinical contexts, especially in therapeutic use, for example, in the treatment of diabetes (Patil et al., 2015). These enzymes could be found in different organisms, including animals, plants, and microorganisms, particularly fungi (Vardhini and Irfath, 2013; Orlandelli et al., 2015).

According to Choi et al. (2005), the production of extracellular enzymes by endophytes may be involved in the host plant's resistance strategy against phytopathogenic microorganisms, or in the improvement of the plant's nutrition.

The numerous species of foliar endophytic fungi that inhabit plants of medicinal and economic importance represent a significant component of environmental microbial diversity. Moreover, they serve as a source of chemical compounds of medicinal and industrial consequence, including in their role as enzyme producers. Our results show that the composition and abundance of endophytic fungi differed among the studied plants, and that these fungi demonstrate potential as sources of enzymes of great commercial and biotechnological value.

Furthermore, enzymatic profiling may be used as an initial screen to select fungi capable of producing such proteins, and to provide preliminary information concerning the range of enzymes involved in the endophyte-host interaction. However, the technique applied in the present work did not yield quantitative results. With the aim of using these fungi in industrial applications as enzyme producers or biotransformation agents, future quantitative assays are required, including tests on agro-industrial wastes.

\section{Conflicts of interest}

The authors declare no conflict of interest.

\section{ACKNOWLEDGMENTS}

The authors would like to thank the Complexo de Centrais de Apoio à Pesquisa (COMCAP/UEM) for sequencing the ITS1-5.8S-ITS2 regions; thanks are due to CAPES (Coordenação de Aperfeiçoamento de Pessoal de Ensino Superior) for Master's scholarships (R.N. Alberto and J.C. Polonio) and CAPES/PNPD-UEM for the post-doctoral scholarship (A.T. Costa). The authors would also like to thank CNPq (\#311534/2014-7 and \#447265/20148) and Fundação Araucária (\#276/2014) for funding the current research.

\section{REFERENCES}

Almeida TT, Orlandelli RC, Azevedo JL and Pamphile JA (2015). Molecular characterization of the endophytic fungal community associated with Eichhornia azurea (Kunth) and Eichhornia crassipes (Mart.) (Pontederiaceae) native to the Upper Paraná River floodplain, Brazil. Genet. Mol. Res. 14: 4920-4931 http://dx.doi.org/10.4238/2015. May.11.25.

Anbu P, Gopinath SCB, Cihan AC and Chaulagain BP (2013). Microbial enzymes and their applications in industries and medicine. BioMed Res. Int. 204014: 10.1155/2013/204014.

Bernardi-Wenzel J, García A, Filho CJ, Prioli AJ, et al. (2010). Evaluation of foliar fungal endophyte diversity and colonization of medicinal plant Luehea divaricata (Martius et Zuccarini). Biol. Res. 43: 375-384 http://dx.doi. org/10.4067/S0716-97602010000400001.

Bezerra JD, Nascimento CC, Barbosa RdoN, da Silva DC, et al. (2015). Endophytic fungi from medicinal plant Bauhinia forficata: Diversity and biotechnological potential. Braz. J. Microbiol. 46: 49-57 http://dx.doi.org/10.1590/S1517$\underline{838246120130657 .}$

Genetics and Molecular Research 15 (4): gmr15049016 
Choi YW, Hodgkiss IJ and Hyde KD (2005). Enzyme production by endophytes of Brucea javanica. International J. Agric. Technol. 1: 55-66.

D'Souza MA and Hiremath KG (2015). Isolation and bioassay screening of medicinal plant endophytes from Western Ghats forests, Goa, India. Int. J. Adv. Res. Biol. Sci. 2: 176-190.

de Souza PM and de Oliveira Magalhães P (2010). Application of microbial $\alpha$-amylase in industry - A review. Braz. J. Microbiol. 41: 850-861 10.1590/S1517-83822010000400004.

Desire MH, Bernard F, Forsah MR, Assang CT, et al. (2014). Enzymes and qualitative phytochemical screening of endophytic fungi isolated from Lantana camara Linn. leaves. J. Appl. Biol. Biotechnol. 2: 1-6 10.7324/ JABB.2014.2601.

Duza MB and Mastan SA (2013). Microbial enzymes and their applications - a review. Indo Am. J. Pharmaceut. Res. 3: 6208-6219.

Eriksson OE and Hawksworth DL (2003). Saccharicola, a new genus for two Leptosphaeria species on sugar cane. Mycologia 95: 426-433. http://dx.doi.org/10.2307/3761884

Ferreira DF (2011). Sisvar: a computer statistical analysis system. Cienc. Agrotec. 35: 1039-1042 10.1590/S141370542011000600001.

García A, Rhoden SA, Rubin Filho CJ, Nakamura CV, et al. (2012). Diversity of foliar endophytic fungi from the medicinal plant Sapindus saponaria L. and their localization by scanning electron microscopy. Biol. Res. 45: 139-148 http:// dx.doi.org/10.4067/S0716-97602012000200006.

Gomes RR, Glienke C, Videira SI, Lombard L, et al. (2013). Diaporthe: a genus of endophytic, saprobic and plant pathogenic fungi. Persoonia 31: 1-41 http://dx.doi.org/10.3767/003158513X666844.

Gupta S, Kaul S, Singh B, Vishwakarma RA, et al. (2016). Production of gentisyl alcohol from Phoma herbarum endophytic in Curcuma longa L. and its antagonistic activity towards leaf spot pathogen Colletotrichum gloeosporioides. Appl. Biochem. Biotechnol. [Epub ahead of print] 10.1007/s12010-016-2154-0.

Jain P, Aggarwal V, Sharma A and Pundir RK (2012). Screening of endophytic fungus Acremonium sp. for amylase production. Int. J. Agric. Technol. 8: 1353-1364.

Kedar A, Rathod D, Yadav A, Agarkar G, et al. (2014). Endophytic Phoma sp. isolated from medicinal plants promote the growth of Zea mays. Nusantara Bioscience 6: 132-139 10.13057/nusbiosci/n060205.

Keller NP, Turner G and Bennett JW (2005). Fungal secondary metabolism - from biochemistry to genomics. Nat. Rev. Microbiol. 3: 937-947 http://dx.doi.org/10.1038/nrmicro1286.

Kusari S, Singh S and Jayabaskaran C (2014). Biotechnological potential of plant-associated endophytic fungi: hope versus hype. Trends Biotechnol. 32: 297-303 http://dx.doi.org/10.1016/j.tibtech.2014.03.009.

Leme AC, Bevilaqua MR, Rhoden SA, Mangolin CA, et al. (2013). Molecular characterization of endophytes isolated from Saccharum spp based on esterase and ribosomal DNA (ITS1-5.8S-ITS2) analyses. Genet. Mol. Res. 12: 4095$4105 \mathrm{http} / / / \mathrm{dx}$.doi.org/10.4238/2013.September.27.11.

Manamgoda DS, Rossman AY, Castlebury LA, Crous PW, et al. (2014). The genus Bipolaris. Stud. Mycol. 79: 221-288 http://dx.doi.org/10.1016/j.simyco.2014.10.002.

Meng L, Sun P, Tang H, Li L, et al. (2011). Endophytic fungus Penicillium chrysogenum, a new source of hypocrellins. Biochem. Syst. Ecol. 39: 163-165 http://dx.doi.org/10.1016/j.bse.2011.02.003.

Mishra Y, Singh A, Batra A and Sharma MM (2014). Understanding the biodiversity and biological applications of endophytic fungi: a review. J. Microb. Biochem. Tech. S8: 004. http://dx.doi.org/10.4172/1948-5948.S8-004

Onofre SB, Mattiello SP, da Silva GC, Groth D, et al. (2013). Production of cellulases by the endophytic fungus Fusarium oxysporum. J. Microbiol. Res. 3: 131-134 http://dx.doi.org/10.5923/j.microbiology.20130304.01.

Orlandelli RC, Alberto RN, Rubin Filho CJ and Pamphile JA (2012). Diversity of endophytic fungal community associated with Piper hispidum (Piperaceae) leaves. Genet. Mol. Res. 11: 1575-1585 http://dx.doi.org/10.4238/2012.May.22.7.

Orlandelli RC, de Almeida TT, Alberto RN, Polonio JC, et al. (2015). Antifungal and proteolytic activities of endophytic fungi isolated from Piper hispidum Sw. Braz. J. Microbiol. 46: 359-366 http://dx.doi.org/10.1590/S1517838246220131042.

Pamphile JA and Azevedo JL (2002). Molecular characterization of endophytic strains of Fusarium verticillioides (Fusarium moniliforme) from maize (Zea mays L). World J. Microbiol. Biotechnol. 18: 391-396 http://dx.doi. org/10.1023/A:1015507008786.

Patil MG, Pagare J, Patil SN and Sidhu AK (2015). Extracellular enzymatic activities of endophytic fungi isolated from various medicinal plants. Int. J. Curr. Microbiol. Applied Sci. 4: 1035-1042.

Raeder U and Broda P (1985). Rapid preparation of DNA from filamentous fungi. Lett. Appl. Microbiol. 1: 17-20 http:// dx.doi.org/10.1111/j.1472-765X.1985.tb01479.x.

Rai MK, Tiwari VV, Irinyi L and Kövics GJ (2014). Advances in taxonomy of genus phoma: polyphyletic nature and role of phenotypic traits and molecular systematics. Indian J. Microbiol. 54: 123-128 http://dx.doi.org/10.1007/s12088013-0442-8.

Genetics and Molecular Research 15 (4): gmr15049016 
Raju DC, Thomas SM and Thomas SE (2015). Screening for extracellular enzyme production in endophytic fungi isolation from Calophyllum inophyllum L leaves. J. Chem. Pharm. Res. 7: 900-904.

Rhoden SA, Garcia A, Rubin Filho CJ, Azevedo JL, et al. (2012). Phylogenetic diversity of endophytic leaf fungus isolates from the medicinal tree Trichilia elegans (Meliaceae). Genet. Mol. Res. 11: 2513-2522 http://dx.doi. org/10.4238/2012.June.15.8.

Sakayaroj J, Preedanon S, Supaphon O, Jones EBG, et al. (2010). Phylogenetic diversity of endophyte assemblages associated with the tropical seagrass Enhalus acoroides in Thailand. Fungal Divers. 42: 27-45 http://dx.doi. org/10.1007/s13225-009-0013-9.

Sudha V, Govindaraj R, Baskar K, Al-Dhabi NA, et al. (2016). Biological properties of endophytic fungi. Braz. Arch. Biol. Technol. 59: e16150436 http://dx.doi.org/10.1590/1678-4324-2016150436.

Sunitha VH, Nirmala Devi D and Srinivas C (2013). Extracellular enzymatic activity of endophytic fungal strains isolated from medicinal plants. World J. Agr. Sci. 9: 01-09. http://dx.doi.org/10.5829/idosi.wjas.2013.9.1.72148

Suryanarayanan TS, Thirunavukkarasu N, Govindarajulu MB, Sasse F, et al. (2009). Fungal endophytes and bioprospecting. Fungal Biol. Rev. 23: 9-19 http://dx.doi.org/10.1016/j.fbr.2009.07.001.

Tamura K, Peterson D, Peterson N, Stecher G, et al. (2011). MEGA5: molecular evolutionary genetics analysis using maximum likelihood, evolutionary distance, and maximum parsimony methods. Mol. Biol. Evol. 28: 2731-2739 http://dx.doi.org/10.1093/molbev/msr121.

Vardhini SRD and Irfath M (2013). Isolation, production, purification and applications of proteases from Pseudomonas aeruginosa. Vedic Res. Int. Biol. Med. Chem. 1: 69-73 http://dx.doi.org/10.14259/bmc.v1i2.77.

Venkatesagowda B, Ponugupaty E, Barbosa AM and Dekker RF (2012). Diversity of plant oil seed-associated fungi isolated from seven oil-bearing seeds and their potential for the production of lipolytic enzymes. World J. Microbiol. Biotechnol. 28: 71-80 http://dx.doi.org/10.1007/s11274-011-0793-4.

Wang LW, Xu BG, Wang JY, Su ZZ, et al. (2012). Bioactive metabolites from Phoma species, an endophytic fungus from the Chinese medicinal plant Arisaema erubescens. Appl. Microbiol. Biotechnol. 93: 1231-1239 http://dx.doi. org/10.1007/s00253-011-3472-3.

White TJ, Bruns T, Lee S and Taylor J (1990). Amplification and direct sequencing of fungal ribosomal RNA genes for phylogenetics. In: PCR protocols. A guide to methods and applications (Innis MA, Gelfland DH, Sninsky JJ and White TJ, eds.). Academic Press, San Diego, 315-322.

Genetics and Molecular Research 15 (4): gmr15049016 